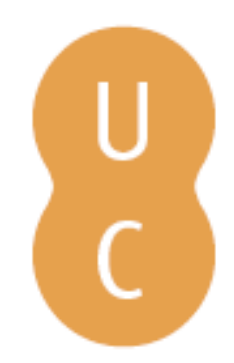

\title{
nommalina
}

\section{A Tour with Fred Vondracek to Hotspots of Occupational Development}
Autor(es): $\quad$ Obschonka, Martin; Pavlova, Maria; Schmitt-Rodermund, Eva; Silbereisen, Rainer K.

Publicado por: Imprensa da Universidade de Coimbra

URL

persistente: URI:http://hdl.handle.net/10316.2/43651

DOI: $\quad$ DOl:https://doi.org/10.14195/978-989-26-1451-9_4

Accessed : $\quad$ 26-Apr-2023 11:18:37

A navegação consulta e descarregamento dos títulos inseridos nas Bibliotecas Digitais UC Digitalis, UC Pombalina e UC Impactum, pressupõem a aceitação plena e sem reservas dos Termos e Condições de Uso destas Bibliotecas Digitais, disponíveis em https://digitalis.uc.pt/pt-pt/termos.

Conforme exposto nos referidos Termos e Condições de Uso, o descarregamento de títulos de acesso restrito requer uma licença válida de autorização devendo o utilizador aceder ao(s) documento(s) a partir de um endereço de IP da instituição detentora da supramencionada licença.

Ao utilizador é apenas permitido o descarregamento para uso pessoal, pelo que o emprego do(s) título(s) descarregado(s) para outro fim, designadamente comercial, carece de autorização do respetivo autor ou editor da obra.

Na medida em que todas as obras da UC Digitalis se encontram protegidas pelo Código do Direito de Autor e Direitos Conexos e demais legislação aplicável, toda a cópia, parcial ou total, deste documento, nos casos em que é legalmente admitida, deverá conter ou fazer-se acompanhar por este aviso. 
JOAQUIM ARMANDO FERREIRA MATTHIAS REITZLE

EDUARDO SANTOS (EDS.)

\section{CAREER \\ DEVELOPMENT \\ IN CONTEXT}

FESTSCHRIFT FOR

FRED VONDRACEK 


\title{
I V
}

\section{A TOUR WITH FREDVONDRACEK TO HOTSPOTS OF OCCUPATIONAL D E V ELOPM E N T}

\author{
Martin Obschonka ${ }^{1}$; martin.obschonka@qut.edu.au \\ Maria Pavlova²; maria.pavlova@uni-jena.de \\ Eva Schmitt-Rodermund ${ }^{2}$; eva.schmitt-rodermund@uni-jena.de \\ Rainer K. Silbereisen²; rainer.silbereisen@uni-jena.de \\ https://doi.org/10.14195/978-989-26-1451-9_4
}

\begin{abstract}
The chapter describes the profound impact Fred Vondracek's work on contexts and dynamics of vocational development had on the "Human development in times of social change"-research group lead by Rainer K. Silbereisen in Germany over the past 30 years. We discuss the most central findings of our research group against the backdrop of Fred Vondracek's work, using examples of various interdisciplinary, large-scale research projects. For example, we discuss his influence, both in terms of his theorizing and empirical works, with regard to a) entrepreneurship research within our group invol-
\end{abstract}

\footnotetext{
${ }^{1}$ QUT Business School, Queensland University of Technology, Australia

2 Center for Applied Developmental Science, University of Jena, Germany
} 
ving psychologists and economists, b) work by a large research consortium examining how individuals negotiate work, family, and civic roles in times of recent social change in Germany and Poland, a project that involved psychologists, sociologists, and economists, and c) developmental research on the German reunification as a prime example of massive and rapid social change. We acknowledge Fred Vondracek's role as an inspiring source. His creative mindset and great support for research and application in human development aim at a better world for young people struck by global social change. Keywords: social change, career development, entrepreneurship, civic engagement, context

\section{Introduction}

If I remember correctly, I (RKS) met Fred Vondracek for the first time during a visiting professorship I spent at the Pennsylvania State University, USA, in 1987/88. During my stay I was very much impressed by a man who had beaten the odds and developed from a young person in Germany with a degree as a professional tile setter to an immigrant and later naturalized citizen in the USA, who after having crossed the ocean attended college and completed a $\mathrm{PhD}$, and when I met him had already been a Department Head at this university. For the notorious inflexibility of the German educational system at that time, this was an almost unbelievable career. I learned that his scientific interests were in vocational development and met some of his colleagues and mentors, but none of this had much to do with my own professional development and research interests - at least so I thought. 


\section{Prelude}

At that time I was still busy with studies on puberty on the one hand and youthful problem behavior on the other. This was due to the fact that since the early 1980s during my tenure as faculty at the Berlin University of Technology I had pursued a research program on substance use in youth. I also compared this problem behavior between German and Polish samples, and learned the lesson that one can only study such issues when they are embedded in the normative psychosocial development of young people. That I had included data on pubertal development in our survey was rather unusual at that time in Germany for a young scholar who, like most of his generation, believed in the power of the social context and the opportunities or constraints for healthy development emanating from there. The fact that I was able to compare samples from Berlin (West) and Warsaw (Poland) was in itself a message - at that time of the Cold War such collaborations between East and West were rather unusual, especially on such a sensitive topic.

I should add at this point that my own background was in lifespan developmental psychology, which I owed to people like the late Paul Baltes, with whom colleagues and I had established one of the first systematic doctoral fellowship programs in Germany on human development. Only when I was at Penn State did I learn about Fred's book on "Career Development: A Life-Span Developmental Approach" (Vondracek, Lerner, \& Schulenberg, 1986).

After a most influential experience in the USA, in 1989 I had another encounter with Fred Vondracek, this time at my then academic home, the University of Giessen in Germany. Together with my colleague Eberhard Todt I had organized an 
international conference. Todt was motivated to expand his contacts to international researchers on adolescence, especially on topics like interest development and values. I knew that Fred Vondracek could help with his expertise and contacts, so I remember suggesting inviting him for an extended guest visit. This experience was also relevant for the book based on the conference that in its title explicitly mentioned context - a term that became crucial in the future of our collaboration with Fred: "Adolescence in context: The interplay of family, school, peers, and work in adjustment" (Silbereisen \& Todt, 1994).

The Giessen experience turned out to be very fruitful - Eberhard Todt not only had an academic interest in the development of interests in adolescence, and had authored widely received books on the topic in Germany, but was also the developer of a "Differential Interest Test," and could look back on real-life experience in career counseling based on his approach and the DIT. This was obviously a stimulating exchange because Fred Vondracek's interest in career development appeared to me also rooted in his personal experiences, and as I learned only then, he also had a background in clinical consulting, which he had done for years.

Joint Steps to New Heights

In the time before 1992, the year I moved from Giessen to the Pennsylvania State University to join the faculty of the Department of Human Development and Family Studies, I was involved in two research projects that, unknown to me then, brought my contacts with Fred Vondracek to fruition. First, in Giessen we conducted interdisciplinary research on a particular group of immigrants to Germany, ethnic Germans ("Aussiedler") from the former Soviet Union who as a diaspora group had resettled in Germany, the country their ancestors had left sometimes hundreds of years ago. This endeavor represented 
a lasting experience in my scientific life because it told me that acculturation to a new context may take a long time, even when one apparently shares the same cultural roots. This is especially true when acculturation concerns traditional beliefs held among the immigrants, whereas acculturation may happen rather quickly when the pragmatics of the new everyday life are the drivers of change.

Our prime research focus was "developmental timetables" in adolescence, that is, the age at which people experience or actually pursue the transition to advanced levels of development. Examples are the timing of puberty mainly driven by biology, as already mentioned, but also the timing of new psychosocial tasks such as the first autonomous decisions in everyday life or the timing of the first romantic involvement, which reflect advances in cognitive and social development. There are also more institutionalized tasks, revealing the influence of social institutions and cultural orientations, such as the timing of beginning occupational plans during adolescence or the timing of marriage in early adulthood (Juang, Reitzle, \& Silbereisen, 2000). This research in a sense never left me we still analyze data of that project and it was also the origin of a new research endeavor that begun in 2006. The studies compared natives, diaspora migrants, and minorities between Israel and Germany (Silbereisen, Titzmann, \& Shavit, 2014), in cross-sections from childhood to early adulthood.

Second, developmental timetables also played a role in another research project that started around the time of German unification. I was involved in the planning of a new representative youth study for West Germany, sponsored like earlier such studies, by the German branch of the international Shell oil company. At that time, the late Juergen Zinnecker undertook every effort so that we could expand the design to the newly accessible East Germany 
(Silbereisen, Vaskovics, \& Zinnecker, 1996). We were again interested in developmental timetables, and by lucky coincidence this concept already had a history in the Shell Study program. It was another opportunity to investigate radical context change and its effects on the change in the stability of developmental timetables. The particular circumstances of unification meant that the societal order of West Germany was superimposed on the East, thereby establishing a situation where people were quickly confronted with a new world concerning politics, economy, law, and social institutions in general. In contrast to immigrants they had stayed put and had not left for a new country, but many of the new challenges were similar to acculturation.

What has all this got to do with Fred Vondracek? Without any foresight, we approached topics which were characteristic of his scientific interest - occupational development. In both research lines we had compared differences between various developmental timetables between groups - young ethnic German immigrants compared to their local counterparts, adolescents compared to parents among the immigrants, and we analyzed in the same fashion young people from the West and the East of Germany, as well as adolescents and parents among those from the East. Regarding immigrant acculturation, in various publications we could show that differences in developmental timetables between our particular groups of immigrants and natives reflected differences in the traditional values concerning the socialization of young people. The timing of romantic involvement, for instance, was definitely later among the immigrants due to their more collectivist and religious backgrounds. Likewise, there was a generation gap in the sense that the adolescents were already more acculturated to Germany than the parents, which set the stage for intra-family conflicts (Schmitt-Rodermund \& Silbereisen, 2009). 
We observed similar trends when comparing East and West Germany at about the time of unification (Silbereisen, 2000), when the traditions distinguishing the two formerly divided regions had not yet waned. As to be expected there was no difference in pubertal timing, but regarding psychosocial timetables the differences we found reflected differences in the organization of daily life - in the East children and adolescents reported autonomy earlier concerning help in the household, which was rooted in the almost normative dual earner family model in the East and its requirements in organizing the family. Really impressive differences, however, appeared in timetables that were based on the timing provided by region-specific social institutions, such as the organization of occupational training and employment opportunities.

In the East, schools and the state were heavily involved in the selection and placement of young people for training and future work, and all this so early in school life was rather predictable in its outcomes for a career. In contrast, the individual degrees of freedom in choosing training and occupation were much higher in the West, but there were also the personal risks of failure. This difference in the opportunity structure could be seen in an equivalent difference in developmental timetables - adolescents in the East reported initial occupational plans much earlier than their counterparts in the West (Schmitt-Rodermund \& Silbereisen 1999; Schmitt-Rodermund \& Silbereisen, 2009). And when it came to what occupation they wanted to strive for, we also found a generational gap we had already observed among immigrants - the young were much more oriented toward the service sector than the primary production sector prevailing among their parents' occupations, thereby also revealing the emerging changes in the new Germany (Reitzle, Vondracek, \& Silbereisen, 1998). 
Now we had occupational development as a focus of joint activities, but the studies and analyses were conceived in a rather simple fashion. We took the reports from timetables, compared groups and contexts, and found differences between the regional contexts that in our view made sense. At this point Fred Vondracek again came to support us conceptually and also in practical terms, first during a visit at the University of Jena in the former East Germany, my new place after Penn State, and later in his role as Co-PI of a Penn State-Jena exchange program funded for about a decade by the German Academic Exchange Service (DAAD). Of note is that in appreciation of his support in rebuilding the psychology program in Jena after unification, he was appointed "Honorarprofessor" (the American equivalent Adjunct Professor does not carry well the honor implicated by the appointment). First, thanks to his thinking about the antecedents and concomitants of career development we were able to embed conceptually the information on timetables in other issues of career development, and in this way developed a better understanding of what we had gathered with our data, and also what we had overlooked. He was crucial in helping to explore the role of the context much deeper than before. One consequence, accomplished not only due to his thinking but certainly also with much encouragement on his side, was to pursue a period comparison between the already mentioned data gathered soon after unification in 1991 and a new parallel survey carried out in 1996. The first basically represented the situation still much influenced by the former East Germany but under the impression of the growing economic difficulties, while the second, five years later during the transformation process, was already characterized by the functioning of the new societal order.

What we had found as differences when comparing East and West in 1991 obviously appeared attenuated in 1996 - the 
timing concerning occupational development was now about the same, a few years after unification. In our view the relevance of this result goes beyond the specific topic - we deem it proof for the view that human development is pretty much under the influence of the ecology and its change, and that depending on the power of such "social clocks", change can occur rather rapidly. We studied the role of the context further and using the example of financial self-sufficiency could show that the change in timetables was indeed in part rooted in the on average, longer school education and growing unemployment in the new Germany (Reitzle \& Silbereisen, 2000). Similarly, differences in the timing of autonomy development earlier in adolescence were related to the new context.

In sum, from the late 1980s Fred Vondracek had a profound influence on the research group's orientation concerning the influence of large-scale contexts and their change due to cultural and societal transitions, first in Giessen and then in Jena. Furthermore, he instilled an interest in occupational development and work roles more generally across the life span. Since then a lot has happened and the remainder of this chapter is devoted to that. Out of a larger substantive array we have chosen two broad topics that pay tribute to his work, without claiming his responsibility for what we pursued and what we probably did wrong or not as well as he would have done it.

First, we will address our research on psychological roots and outcomes of entrepreneurship, planned and conducted against the past experiences with social change mentioned, and obviously Fred Vondracek's views played a role again. Entrepreneurship is often seen as a driver of economic development, much more so than traditional industries, and thus is especially important in the times of rapid political, social, and economic change we have been interested in. Germany 
has too few entrepreneurs compared to other countries and consequently attracting young people to such career pathways is of crucial importance. Further, entrepreneurship was not encouraged in the former East of the country, and thus once again we can learn whether the change of contexts turns out to be a driver of development. In other words, possibilities for entrepreneurship are one of the benefits of German unification, and we didn't want to look only at the challenges that are so prominent in the public discourse. Second, we report about our life-span research on individual adjustment and development in the work, family, and civic domains, covering how people deal with uncertainties prevalent for many during the second decade after German unification. The situation in the mid2000 s was a mixture of still existing post-unification tensions with new challenges rooted in globalization in general and the financial crises of the Great Recession in particular. This research program is based on conceptual principles that we share with Fred Vondracek, not only the emphasis on the role of contexts, from interpersonal to societal institutions, but also the interest in differences and commonalities between stages of the life-span. The chapter closes with remarks on the social policy relevance of our research endeavors, given the many countries in the world that are currently undergoing political, social, and economic transitions and transformations.

\section{Entrepreneurship across Time and Space}

Having taken part in work on topics of adolescent development originating in the research group at the Berlin University of Technology and then transferred to the University of Giessen, mostly concerning value orientations and puberty, I (ESR) 
started off into my own research work with the acculturation project on ethnic German immigrants mentioned at the outset. It must have been around that time when I first met Fred Vondracek. It speaks for itself that I do not even remember not to have known him; it seems that he was part of the family from those days on, and we certainly owe it to him that we jumped on an offer to apply for funds from the government to study entrepreneurship development.

It was about the same time that plans got tied up for a research semester that I spent at the Pennsylvania State University in the second half of 1997, preparing for the data collection of the entrepreneurship study. Fred's approach to vocational development in the context of parents, schools, parents' work, the community, and society as a whole, and his view of an active person making choices and exploring occupational options within that network, fitted in with the notion of "development as action in context" (Silbereisen, Eyferth, \& Rudinger, 1986). This inspired my own ideas about career development, ideas that took shape in two different ways. First, back in Jena, I taught my first seminar on career-related issues, using models and research Fred had pointed out. Names, models, and research work from people like Mark Savickas, David Blustein, John Holland, Donald Super, and others had started to mean a lot to me, not only because Fred was so inspired by their approaches but also because he introduced me to some of these great theoreticians in person.

The second momentum was that I started to dig through the Shell data in order to find ways to study vocational behavior and career development in German youth. We looked into career aims and career maturity of young people in East and West by way of reanalyzing the data not originally meant for the purpose (Schmitt-Rodermund \& Silbereisen, 1998; 
Christmas-Best \& Schmitt-Rodermund, 2001). Furthermore we compared the relationship of exploration behavior and breadth of interests in East and West German adolescents. We found that childhood exploratory behaviors were inspired by joint activities with parents in East and West alike. Exploration pursued by adolescents, however, related to the amount of childhood exploration only. Thus it seemed that parents' time frame or window of opportunity for an impact on exploratory behavior was childhood rather than adolescence, which is probably good to know when planning for interventions aiming to increase adolescent vocational exploration and help adolescents to make better occupational choices (Schmitt-Rodermund \& Vondracek, 1999; Kracke \& Schmitt-Rodermund, 2001).

Later the results of the studies on exploration became influential for a new program on the crystallization of entrepreneurial interests in adolescents which I started with Elke Schröder. She found that entrepreneurial activities in the classroom and games set up to shed light on one's personality can help adolescents without firsthand experience through a family model of self-employment to develop clear interests in favor of or against an entrepreneurial career later in life (SchmittRodermund \& Schröder, 2004). It is not that everyone should become an entrepreneur as obviously many adolescents do not have the characteristics making an entrepreneurial career an option, but certainly those young people who have the right personalities and ideas should start their own companies (Schröder \& Schmitt-Rodermund, 2006, 2007).

The parental model and parenting were candidates for factors we suspected to be important for a career decision for entrepreneurship, but certainly there were additional influences at work. Fred and I started to discuss the issue of expenditure of 
effort, that is, the entire motivational background so important for entrepreneurship. The curiosity to learn something new, the willingness to do work in order to gain insights into things these were topics which really excited him. I remember him talking about his grandson Devyn, who was a wonderful example of a kid expending effort, but I kept thinking to myself that the true example of someone expending effort was Fred Vondracek himself, who is among the most curious but also among the most stubborn people I know when it comes to getting somewhere, understanding something, working hard, and having a hell of a good time with it.

Meanwhile I had started to collect entrepreneurship-related data in samples of students and self-employed adults. We found that the expenditure of effort mediated the relationship between a parental role model of entrepreneurship and the willingness of the adolescents to follow their parents' footsteps to become self-employed one day. Young people growing up with a background of a family business, who at the same time were not curious and energetic about learning new things, were positive about one thing: That they would not be entrepreneurs by the age of 40. To us, this made perfect sense and added some more insight into the role of a parental model in the development of personal occupational choices. The entire idea that it is not the parental model as such but rather the happiness and devotion of parents with their jobs which contribute to their offspring's career interests has laid the foundation for a new research program (together with Elke Schroder), aiming at the study of family businesses and the antecedents of succession together with Elke Schröder. We were able to find support for the expectations Fred and I had discussed years earlier (Schröder, Schmitt-Rodermund, \& Arnaud, 2011), in particu- 
lar the willingness to join the family business being related to parental support in issues of career decision making and exploration on the one hand and adolescents' perceptions about their entrepreneurial competences on the other. Young people who were confident about their skills and at the same time had parents who supported any autonomous career decision were interested in taking over the wheel. If parents however tried to issue strong control concerning their offspring's willingness to take over the family company, the younger generation reported feeling obligated to act as heirs of their parents, yet they did not see themselves in their parents' shoes (Schröder \& Schmitt-Rodermund, 2013). Given that about $90 \%$ of all companies in Germany are family owned, the issue of how to pass on one's lifetime work to the next generation is all but trivial and further research will be needed to provide parents with reliable knowledge on how to prepare (and what to avoid!) for tackling the question of succession in the family business.

With regard to the idea of expending effort, the issue of an entrepreneurial personality got me hooked for the following years. McClelland had the wonderful notion that someone with an entrepreneurial personality in a Buddhist society might as well become a Buddhist monk rather than a businessperson. Transferred to a Western context one may expect that a parental model of entrepreneurship may serve as the context which is likely to trigger entrepreneurial activity (McClelland, 1961, p. 239). Now we knew some more about characteristics of such a context within families, however personality traits, the other side of the equation, was somewhat a black box. To me, Fred served as a wonderful example of someone who follows his dreams against all odds, nevertheless I was chewing on the problem that it was not 
one single trait or the addition of a few characteristics that made him and others perfect examples of entrepreneurial personalities but rather a certain "profile," a particular combination of different personality aspects.

If Fred Vondracek can be considered the father of all our undertakings to study entrepreneurship, Lea Pulkkinen with her Jyväskylä Youth Longitudinal Study may be seen as the mother. With a focus on problem behavior, some of her work was inspired by the so-called person-oriented approach (Bergman \& Magnusson, 1997) and she assumed that undue personality traits in their combination and interaction among each other contribute to problems later in life. Individual unemployment, for instance, especially when paralleled by precarious economic conditions on the societal level, was shown to be a possible consequence of the interplay of early personality characteristics (impulsivity) and resulting maladaptation due to interaction with challenging contexts like school over time, a view which helped us to find a new perspective on the issue of the relationship between personality and entrepreneurial activity (Kokko, Bergman, \& Pulkkinen, 2003). Rather than seeing all the different traits of, for instance, the Big Five as separate contributions to behavior and development, we more and more adopted a view on the entrepreneurial personality as a profile of these traits, characterized by a particular constellation of high and low manifestations. High extraversion, openness, and conscientiousness, but low neuroticism and agreeableness were considered as the anchor points describing an entrepreneurial personality.

Moreover, we started brooding about possible connectors and mediators of childhood and adolescent personalities to adult vocational choices and career success. Again, Fred Vondracek's ideas on vocational interests and their devel- 
opment over time were highly influential, and so it comes as no surprise that we considered early entrepreneurial competencies on the one hand and entrepreneurial interests on the other, as two stepping stones leading the way to a career decision into self-employment and entrepreneurship, connecting personality and aspects of parenting with entrepreneurship much later in life.

With this model in mind, we put together a set of studies on entrepreneurship development. In a first step, we combined a number of cross-sectional data sets in order to show the expected relationships in groups of different chronological ages and stages of their career. Adolescents who expected to pursue careers in a setting of self-employment at the same time reported early entrepreneurial competences like leadership (they were speakers in their classrooms or had responsibilities in clubs) and invention (they had invented things more often than others). Moreover they were found to have higher levels of entrepreneurial interests (e.g., were interested to learn about economics or had books on economic topics on their reading list). Entrepreneurial competences and interests these girls and boys had developed in turn were related to the personality profile and to parenting experiences. Adolescents with high levels of extraversion, openness, and conscientiousness, who at the same time were low in agreeableness and neuroticism, that is, those with an entrepreneurial profile, and adolescents who reported many joint activities and decision making with their parents, more often engaged in inventions and leadership activities and reported entrepreneurial interests. Moreover, there was an interaction between parenting style and personality profile: Adolescents with an entrepreneurial personality profile seemed to profit most from joint activities and other signs of authoritative parenting, and one in two of this particular group 
indicated that one day they wanted to start their own company (Schmitt-Rodermund, 2004).

We found more or less the same results for a group of adult business founders, except that in their case the actual number of years of entrepreneurial activity and their entrepreneurial success served as the dependent measure, whereas concerning information on parenting and early interests and competences, we had to rely on retrospective data. This particular characteristic of the data, with information tapping on future behavior in the case of the adolescents and the past for the adult participants in the two samples, made us seek a prospective (longitudinal) data set which would cover both adolescence and adulthood, and would entail personality and parenting information, data on interests and activities as well as biographical information on the careers of the individuals.

Thus, in a second step, we chose to apply for the use of the Terman data, an outstanding data set covering the time of individuals' lives between the 1920s and 1986, which brings about all the different information we had on our wish list. The model outlined above was repeated, and I was happy when I found the exact same relationships in place covering a time span of about 40 years and using data from different sources, that is, parents, teachers, and the target individuals, the so-called Termites.

This parallel set of findings was particularly remarkable as obviously somewhat different questions and instruments had been used reflecting concepts familiar to the researchers of the time decades earlier, but nevertheless of relevance for today's psychological thinking. Once more, an entrepreneurial personality profile and a parenting style characterized by an emphasis on joint activities predicted a higher number of inventions and more leadership activities (both standing for 
entrepreneurial competences in adolescence), and entrepreneurial interests as observed by parents and teachers a year later. Interests and competences in turn related to the ultimate career goal by the end of the time in college: Young people with entrepreneurial interests and competences around the age of 13 reported career aims in economics and self-employment more often than others did. Having such a career goal in turn predicted entrepreneurial activity much later in life (SchmittRodermund, 2007).

Fred Vondracek's impact can be followed throughout the entire project on entrepreneurial activity and continued when we entered a new stage with the Thuringian Founder Study and our then doctoral student Martin Obschonka, who made entrepreneurship his research topic all the way into his first position as a university professor. Whereas above I concentrated on the overall impact of Fred's thinking, the following will illuminate a series of core principles of our own work.

When I (MO) had finished my dissertation project in Rainer Silbereisen's and Eva Schmitt-Rodermund's research group in 2011 (Thuringian Founder Study), I could also look back to a type of intellectual journey and identity development process. When I started to study early developmental precursors of entrepreneurship in adulthood, I found myself being confronted with multi- and interdisciplinary literature with authors from diverse fields such as management research, economics, geography, sociology, and psychology. Although it is clear that interdisciplinary work has diverse benefits for both researchers and the world of practice, it also comes with a lot of challenges. Finding your own way as a young scientist and placing your research in a certain niche can be considerably trickier in a multidisciplinary context than in a mono-disciplinary field, at least judged by my experience. Authors from different fields 
speak different "languages," journals from different fields have different method standards, and, most importantly, different fields offer different role models and "intellectual homes." Although I was very happy to draw from, and continue and extend, our earlier work on entrepreneurship, there was also the challenge that the entrepreneurship research community at that time had not yet developed a substantial interest in developmental research that draws from a life-span perspective. Although such research would have the potential to inform the world of practice (e.g., entrepreneurship education, which is nowadays a major issue on the political agenda in many countries), I was not aware of any other research team investigating a similar topic. This meant that this topic was innovative, which is of course of advantage to a young researcher, but it also meant more uncertainty, fewer academic peers doing similar things, and thus a lack of "brothers and sisters" and senior role models in this specific field of research.

Without a doubt, I owe most of my academic socialization to my doctor "father" and habilitation promoter (the second degree of academic accolades after the $\mathrm{PhD}$, making one eligible for a professor position), Rainer Silbereisen. However, it is also true that at the end of my dissertation project I had come to the conclusion that substantial parts of my doctoral (and later also my postdoctoral) research and my scientific identity had to do with the work of Fred Vondracek. His work offered me a comprehensive, integrative framework that connected many otherwise loose ends. In other words, it reflected and connected many of those core topics that I found to be most relevant for the psychological examination of entrepreneurship. These were: A developmental life-span perspective, an emphasis on the early formative years in childhood and adolescence, a proper contextualization including the consideration of macro-context 
and socio-historical change, a close research-practice link, and an affinity to person-oriented conceptualizations and analyses. Fred's work, maybe more than the work of others, integrated these topics, thereby keeping a strict focus on vocational development, occupational choices, and career success. The following is meant to illustrate how his topics permeated our work.

First, Fred's work on careers and vocational development has a clear reference to the life-span idea (Vondracek et al., 1986), and thus to life-span psychology (Baltes, Lindenberger, \& Staudinger, 2006) and life-course sociology (Elder, 1994). This preference for a life-span perspective may also have to do with the influence of Donald Super, who was one of the very first career researchers who applied a developmental life-span perspective to the field. Super had developed a famous life-span career model (the "career rainbow") (Super, Savickas, \& Super, 1996) that was based on seminal theorizing in developmental psychology such as Charlotte Bühler's work. Fred himself noted in 2001 that life-span psychology and life-course sociology on the one hand, and developmental career research that had started with Super's life-span perspective on the other, show a lot of similarities but rarely concretely refer to each other (Vondracek, 2001). Maybe this was the reason why Fred appeared to be so motivated to connect and integrate both fields in his own work. For example, he often stressed the human agency theorem of lifespan psychology and life-course psychology (see also Silbereisen, Eyferth, \& Rudinger, 1986), according to which individuals are producers of their own (successful) vocational development and occupational future. He further stated that "by having life-span developmental metatheory as its guiding conceptual framework, vocational psychology is well positioned to explore, investigate, and understand the antecedents, concomitants, and consequences of vocational behavior" (Vondracek, 2001, p. 253). 
One concrete example where a life-span perspective has been very useful in guiding research in vocational psychology is the investigation of entrepreneurship. In fact, consistent with the earlier findings (Schmitt-Rodermund, 2004, 2007), a guiding principle of my dissertation was that entrepreneurship (e.g., successful entrepreneurial thinking and acting in the occupational career) is a developmental outcome, and that it essentially requires a life-span perspective to study entrepreneurship (e.g., which connects the early formative years in childhood and adolescence with the vocational development in adulthood). My dissertation and postdoc studies delivered further empirical evidence indicating that the entrepreneur should be understood as a developing individual, which implies that one should consider the complete developmental history. One prevailing but potentially misleading thought in the debate on the design of effective entrepreneurship education programs is that a focus on young and middle adulthood suffices. This view implies that entrepreneurship, in principle, is something that should be best thought of as a field of study in colleges and universities, or that can be best "taught" in the form of public business advice for founders. However, developmentally oriented studies on entrepreneurship strongly indicate that this view falls short in that it really needs a life-span view considering the developing individual and all developmental phases, from childhood to the late stages in the occupational career, to conceive effective educational measures (Obschonka, 2013). Sarah Kösters and I (2011) found that public business advice delivered in the founding phase of new ventures had no measurable economic effects. Those founders who had received such help and advice did not achieve better entrepreneurial success in terms of job creation and financial success than other founders. It might need earlier, longer lasting, and more comprehensive education 
programs to promote entrepreneurial mindsets; programs that would implement a life-span perspective.

This leads to a second principle in Fred's work - his emphasis on the early formative years in childhood and adolescence when studying career outcomes. Although a life-span perspective already entails that one should consider childhood and adolescence, the clear statement in his work is that the early years are formative since they establish the early antecedents of later career outcomes. Fred and his research group had published a wonderful review on child vocational development (Hartung, Porfeli, \& Vondracek, 2005), which reported the richness of the scientific study of early vocational development and of the pathways to occupational careers in adulthood. According to the review, numerous longitudinal studies showed occupational outcomes in adulthood (e.g., career choice and job performance) to be predictable by early characteristics (e.g., child temperament, adolescent competences) and to be linked with age-graded developmental processes (e.g., competence growth, personality development).

In our research on entrepreneurial careers, the early antecedents of entrepreneurial career outcomes such as an entrepreneurial career choice (becoming a business founder) and achieving entrepreneurial success as a founder also turned out to be very important. One example is early, age-appropriate entrepreneurial competencies in adolescence (e.g., leadership, inventing, and commercialization activities in school and leisure time). Using retrospective data from the Thuringian Founder Study, we found such (recalled) early competences to positively predict a) entrepreneurial intentions in adulthood, mediated by entrepreneurial control beliefs (Obschonka, Silbereisen, \& Schmitt-Rodermund, 2010), b) entrepreneurial behavior (Obschonka, Silbereisen, \& Schmitt-Rodermund, 2012), c) those 
skills of business founders that are crucial for entrepreneurial success (Obschonka, Silbereisen, \& Schmitt-Rodermund, 2011), d) an entrepreneurial self-identity as part of the occupational self-concept in adulthood (Obschonka, Silbereisen, Goethner, \& Cantner, 2015), and e) venture creation success in the occupational career of entrepreneurs (Obschonka, Silbereisen, Schmitt-Rodermund, \& Stuetzer, 2011). In an analysis that combined retrospective data from the Thuringian Founder Study with prospective data from the British Cohort Study, we and colleagues from the University of London found that early social competences in childhood and adolescence predicted central outcomes along the venture creation process (entrepreneurial intentions, behavior, and success) (Obschonka, Duckworth, Silbereisen, \& Schoon, 2012). Another example of early developmental precursors is mild rule-breaking behavior in adolescence as a valid predictor of entrepreneurship in the occupational career (Obschonka, Andersson, Silbereisen, \& Sverke, 2013).

Third, Fred's work often stressed the role of the context and context systems that range from proximal developmental contexts (e.g., parents, peer groups) to distal developmental contexts (e.g., the macro-cultural context). His work has demonstrated that a developmental-contextual perspective is necessary to understand why individuals choose certain jobs and careers and why some are more successful than others in a certain job and in the career as a whole. Fred, without a doubt, played a major role in championing the contextual view, which is also illustrated in his research on social change (Vondracek, Ferreira, \& Santos, 2010) - the historical change in macro-context structure and how this macro-level change then affects vocational development at the individual level.

In my dissertation project, I found further support for our hypothesis that the parental context in the form of authoritative 
parenting and early entrepreneurial role models is important for the development of an entrepreneurial mindset because it stimulates early competence growth regarding basic entrepreneurial skills, such as leadership, inventions, and commercialization activities (Obschonka, Silbereisen, \& Schmitt-Rodermund, 2011). By drawing from a social change perspective that examines the everyday manifestations of macro-level changes such as globalization and technological development, we, and a Polish colleague, found indications that entrepreneurs, when compared to employees, enjoy more the positive side of today's social change (e.g., more perceived new opportunities for learning in their daily work) and less the negative side (less strongly perceived increase in uncertainties regarding career planning) (Obschonka, Silbereisen, \& Wasilewski, 2012).

Fourth, Fred's work also highlighted the research-practice link where "science informs practice and practice, in turn, informs science" (Vondracek, 2001, p. 254). Research on careers, as an applied field, has a close connection with the world of practice, for example to the field of career counseling and guidance. Research can provide empirically validated theories of a basic or applied nature that practitioners can then try to employ in the real world for intervention. Likewise, practitioners and their real-world issues can inform the research field of vocational developments (e.g., by suggesting new research topics or by urging research to question and develop established theories and models in the light of new historical and economic developments). This research-practice link is also crucial in entrepreneurship research. For example, developmentally oriented research can inform early education programs (e.g., enterprising courses in schools) about the usefulness and designs of such education measures (e.g., what kind of early competences should be promoted). 
Fifth and finally, since research on vocational development, just like research in psychology in general, deals essentially with the individual, as embedded in various contexts, it might make sense to consider person-oriented concepts and research methods that are better able to capture the individual as a whole than variable-oriented concepts and methods do. In fact, Fred urged career researchers to consider person-oriented methods that prefer looking at intra-individual patterns and processes instead of the purely statistical relationships of variables in a given sample. These statistical relationships (e.g., effects in a standard multiple regression) might not always reflect intra-individual patterns and processes and can thus be somewhat misleading when one is interested in the individual (Vondracek \& Porfeli, 2002).

Such a person-oriented view also played its role in my entrepreneurship research. For example it inspired me to assess the person's entrepreneurial success by taking a career perspective that considers not only one target business the individual had founded but all entrepreneurial activities over the career. Another example is our research on the entrepreneurial personality profile, which is based on Eva Schmitt-Rodermund's studies showing an intra-individual Big Five trait profile (high in extraversion, conscientiousness, and openness, and low in neuroticism and agreeableness) to be particularly predictive of entrepreneurial outcomes. This profile attempts to capture the entrepreneurial personality as a whole instead of studying single traits and their relationships in given samples. In my research I found this profile to predict entrepreneurial outcomes in a more valid and consistent way than the single Big Five dimensions when studied separately. Using large personality datasets we, together with colleagues from the USA, also found the regional prevalence of such an entrepreneurial Big Five profile in the 
US, the UK, and Germany to correspond to the regional entrepreneurship rates within these three countries. Those regions within the US, the UK, and Germany with a higher averaged score in the local population's entrepreneurial Big Five profiles also had higher entrepreneurship rates (Obschonka, SchmittRodermund, Silbereisen, Gosling, \& Potter, 2013).

Whereas the entrepreneurship research was mainly based on samples and studies designed for that purpose, the following demonstrates how the general purpose survey on transformation in Germany during post-unification times was made to speak to topics on occupation and careers. Again, Fred Vondracek's priorities in research played a formative role.

\section{Individuals Negotiating Work, Family, and Civic Roles in Times of Social Change}

In the mid-2000s, we launched a new endeavor within an interdisciplinary research consortium (SFB 580) that put the differential exposure of individuals (not just entire cohorts like in the previous research) to current social change and how they cope with into the foreground. Specifically, drawing on prior examples from the life-course research on perceived economic strain (Conger \& Elder, 1994), we developed assessments of the individually perceived uncertainties concerning one's work and family lives (Tomasik \& Silbereisen, 2009). The items describing uncertainties were formulated such that the possible roots of these experiences in the societal conditions were addressed as background, meaning the still virulent strains of unification, overlaid with globalization and the beginning worldwide financial crisis. By addressing subjective perceptions of social change and in addition individual ways of coping with social 
change, we drew together the individual-agency and structural perspectives on the life-course development and adaptation, an approach also espoused by Fred (Vondracek \& Porfeli, 2002). How this was carried out we demonstrate by the following examples from our research.

With regard to the work domain in particular, our construct of work-related demands of social change (Tomasik \& Silbereisen, 2009), which we sometimes label as perceived occupational uncertainty (e.g., Pavlova \& Silbereisen, 2014), was a response to a call also (but not only) made by Fred (Vondracek, 2001; Vondracek, Ferreira, \& Santos, 2010) for developmental scientists to consider drastic changes in the modern work life, such as growing job insecurity, risks of underemployment, and a need for lifelong learning, that have profound implications for individual careers. In our survey, which drew on large samples from East and West Germany around the mid-2000s, perceived occupational uncertainty obviously functioned as a stressor because there was an association with lower subjective well-being over time (Tomasik \& Silbereisen, 2012). As an instance of the pivotal role of context in individual development (Vondracek et al.,1986), we found that perceived occupational uncertainty, as well as perceived uncertainty in the family domain, was unequally distributed across socioeconomic strata and political regions within Germany (Pinquart, Silbereisen, \& Körner, 2009; Tomasik \& Silbereisen, 2009). Moreover, associations of uncertainties with subjective well-being varied in a meaningful way depending on the regional contexts' economic vitality. For instance, somewhat paradoxically occupational uncertainty seemingly affected well-being less if the unemployment rate in the district where people lived was higher (Pinquart et al., 2009). In economics, such moderation is known as a "social norm" effect (Clark, Knabe, \& Rätsel, 2010). 
Further, our past research addressing the 1990s had not looked at how people actually dealt with the new challenges. We only had results on psychosocial outcomes for groups of individuals living either in the West or in the East of Germany. In the new project, we adapted measures of goal engagement and goal disengagement from Jutta Heckhausen et al.'s life-span theory of control (Heckhausen, Wrosch, \& Schulz, 2010) to assess coping with the demands of social change in the work and family domains. In the spirit of both developmental-contextual (Vondracek et al., 1986) and life-span (Heckhausen et al., 2010) approaches to individual (vocational) development, and concurring with stress and coping research (Folkman \& Moskowitz, 2004), we discovered that the association between perceived uncertainties and lower subjective well-being could be attenuated by opportunity-adequate engagement (Grümer, Silbereisen, \& Heckhausen, 2013; Körner, Reitzle, \& Silbereisen, 2012). That is, if the circumstances allow for individual control of one's actions, then to pursue a resolution of work-related or family demands by active engagement is worthwhile. Otherwise goal disengagement (i.e., distancing from unattainable goals, perhaps to pursue more promising courses of action) is more appropriate (Körner et al., 2012; Pinquart et al., 2009; Tomasik \& Silbereisen, 2012; Tomasik, Silbereisen, \& Heckhausen, 2010). However, in a more recent study, we found that goal engagement was the only predictor of objective career outcomes, such as preventing job loss, job finding, and positive income change, also given unfavorable labor market conditions (Körner, Lechner, Pavlova, \& Silbereisen, 2015). Thus, while goal disengagement might protect subjective well-being under unfavorable circumstances, only active engagement with work-related issues seemed to contribute to objective career success. 
Another priority that Fred, along with others, has often urged developmental and vocational researchers to follow is considering multiple roles and life domains simultaneously, in relation to one another, instead of focusing on only one, such as paid work (Vondracek \& Porfeli, 2002). In line with this requirement, in our research, we considered demands in the work and family (and also other) domains in parallel. We found that, although such demands had negative effects on subjective well-being across domains, certain ways of coping were sometimes more effective or, on the contrary, more maladaptive in one domain (e.g., work) than in another (e.g., family; Grümer et al., 2013; Tomasik et al., 2010).

Furthermore, we recently extended our attention to unpaid, voluntary work in the form of civic engagement, which is undertaken for community and societal benefit, most often under the auspices of voluntary organizations. Our interest in civic engagement was explained by its being a major nonwork domain, which is public (in contrast to family) and of high relevance to societal cohesion. The topic of social change assumed a new dimension here, because civic engagement is a way for individuals to produce social change. This line of research was taken up and eventually led by our then postdoc Maria Pavlova, a Russian migrant to Germany who, beyond her academic accolades gained in her homeland, also accomplished an habilitation within the research group.

In one representative study on this topic (Pavlova \& Silbereisen, 2014), we addressed the relationship between growing occupational uncertainty in Germany during the mid2000 s (the first sample) and early 2010s (the second sample) and individuals' willingness to engage in volunteer work. We questioned the widespread belief that difficulties experienced in the paid work domain deflect individuals from other pursuits, 
especially from voluntary civic activities (Rotolo \& Wilson, 2003). The point is, we argued, that volunteering experience, similarly to more widespread German internships, may sometimes benefit one's career, in particular among labor market entrants, who lack actual work experience. Skills and contacts acquired through volunteering may smooth the transition into the labor market; indeed, many studies have shown that volunteering in young adulthood predicts job finding and later occupational achievement (e.g., Ruiter \& De Graaf, 2009; Wilson \& Musick, 2003). To take individual agency into account, we proposed that those young individuals who employed active engagement coping when facing perceived occupational uncertainty would be more likely to volunteer. Indeed, this was what we found in two independent samples (Pavlova \& Silbereisen, 2014).

However, this was only half of the story. For older workers, we expected to find the opposite pattern, that is, that disengagement coping with perceived occupational uncertainty would be linked to volunteering (Pavlova \& Silbereisen, 2014). Why? For older German workers who are faced with occupational uncertainty (e.g., if they perceive a risk of losing their job and have few opportunities to find another permanent position as they are close to the retirement age), the best way to proceed may be to disengage from work-related goals and to seek alternative pursuits (Heckhausen et al., 2010). Volunteering is exactly the kind of activity that may substitute for paid work at an older age as it has a socially recognized value, is usually undertaken in formal settings (e.g., a voluntary organization), involves social interaction, and brings tangible results (Pavlova \& Silbereisen, 2012). Indeed, we found that goal disengagement in coping with occupational uncertainty prospectively predicted starting volunteer work in older workers, whereas in young labor market entrants, goal disengagement had the opposite (i.e., negative) 
effects on starting volunteer work (Pavlova \& Silbereisen, 2014). Although our age comparisons were cross-sectional, they nicely illustrate that individuals experience distinct concerns and transitions at different stages of their work careers (Savickas, 1997; Vondracek \& Porfeli, 2002) and that individual agency (cf. career adaptability; Super et al., 1996) takes on different forms depending on the life or career stage.

In another recent study (Pavlova, Körner, \& Silbereisen, 2015), we applied the principles of developmental contextualism and the life-span approach (Baltes et al., 2006; Vondracek et al., 1986) to study the correlates of civic engagement. Specifically, we were interested in the roles of multiple contexts of adult development (i.e., family, friends, and community) for civic engagement at different stages of the life span. Accordingly, we compared the effects of interest across four age groups ranging from 18 to 75 years of age. Social-contextual predictors were general support from family and friends and various indicators of positive community functioning. The main lessons learned from this study are that, first, different developmental contexts may have quite different implications for adult civic engagement, from positive (community) to negative (family support), and second, there are both age similarities and age differences in these relationships.

\section{Concluding Remarks}

A particular pleasure in writing this chapter should be mentioned. Apart from the senior author, it was accomplished by three younger scientists each of whom already had made a career by working in a tradition of concepts and contacts that started more than two decades ago. This is testimony to an 
intergenerational linkage of ideas that hopefully help to make the world a better place.

The common denominator of the concepts and research examples presented in this chapter follows an old trace in the work of the research group, with way stations at a number of universities (now using the official names): Technische Universität Berlin, Justus-Liebig-Universität Giessen, The Pennsylvania State University, and Friedrich-Schiller-Universität Jena. Berlin had a special focus on human development in the life-span fashion, Giessen was strong in research on adolescence as was Penn State, and Jena was home to the biggest special research program (SFB 580, funded by the German National Science Foundation) on Germany in its new statehood after the end of the Cold War and its lasting transformation after unification.

We were lucky enough to be able to choose research topics that reflected personal interests and societal needs. That career development, broadly speaking, played a crucial role in the research agenda was not the result of a plan, but occurred due to a particular constellation of motives and opportunities. The interest in how young people deal with age-typical developmental tasks gained a particular flavor by the challenges on the societal level - unexpected waves of immigration to a country that was not prepared for this meeting of cultures, and the radical transition of the political system as a consequence of the disruptions within the former Soviet Bloc. Both types of changes in contexts were a hotbed of possible changes in human development. More specifically, both phenomena presented us with a unique opportunity to find out about the contextual malleability of psychosocial development under special circumstances that shake up the usual constellation of person and context.

We were prepared for such research endeavors by a long-lasting interest in other contextual conditions, such as economic 
hardship and its consequences in countries differing in the political background (Silbereisen, Walper, \& Albrecht, 1990). Related to that we had organized a conference and edited a book on "Development as Action in Context" (Silbereisen et al., 1986). However, it needed an initial spark to bring it all together under the rubric of individuals' participation in the world of work, a case in point for a developmental domain that has been challenged by "rapidly accelerating rate of change and diversity of both individual and social dynamics" (Vondracek et al., 2010, p. 126). The result of such changes worldwide are the threat to job security and career advancement as many had enjoyed in the past, and this for the better part is due to the change or even disappearance of social structures that used to channel individuals into clearly defined occupational pathways (paraphrasing Vondracek et al., 2010). Fred has been the pilot (in the old understanding of an experienced person guiding the way through uncharted waters) for quite some time in this research, by lending credence to our search for social institutions that reshape development by their own change due to political, social, and economic change. Our general case in point was migration and societal transformation, and our particular example was change of a system of education and training and the new uncertainties in the domains of work and family. We found a rather specific and easily traceable effect of such changes.

The exchange with Fred Vondracek took place in a particular historical period. The late 1980s to today (2015) was a time of rapid political, social, and economic change, starting with the demise of the "state socialism" led by the former Soviet Union, followed in the early 2000 s by intensified challenges of globalization during the transformation period in the new countries of the former Soviet Bloc, and subse- 
quently superimposed by the Great Recession beginning in 2008 and the sovereign debt crisis (Reinhart \& Rogoff, 2013), particularly in Southern European countries, with interest rates for government bonds increasing by up to almost $30 \%$. As we know today those years were especially problematic for young people, as indicated by exploding unemployment rates, reaching almost $50 \%$ in some regions. Although Germany was better off than most countries, there was also a lot of friction (Statista, 2015).

All this meant that career development became an issue of highest priority, and in particular the "continental welfare regime" with its support against challenges of social change (Arts \& Gelissen, 2002) and the dual vocational training system (Euler, 2013) received a lot of new interest in Europe. This was so because the German youth unemployment rates were among the lowest during the entire period in all regions.

Of course there is always the question of how long effects of social change last over periods of the life span. For Germany meanwhile some longitudinal studies exist that document the development of young people in former East Germany, starting several years before unification at the age of 14 in 1987 and running until age 40 in 2013/14 (Berth, Förster, Brähler \& Stöbel-Richter, 2007). What is important for the current argument of the importance of the historical/social context is the fact that even 25 years after the fall of the Berlin Wall, about one in four believe that they were losers of unification. Furthermore, the time people guessed it would take until East and West grew together somewhat surprisingly increased over all those years, and stands now at 25 years. Indeed, it is like a migration experience affecting more than one generation. Moreover, the political beliefs these people showed when they were young in East Germany before unification still distin- 
guishes them in middle adulthood. In other words, this is a case of "the past is not dead, it's not even past." Interestingly, we ourselves had access to parts of that dataset and investigated different trajectories of adolescent substance use after unification (Wiesner, Weichold, \& Silbereisen, 2007; Wiesner, Weichold, \& Silbereisen, 2008). Consequently our research on behavior and development after unification is using the East/ West distinction of the country as an important developmental context, following Vondracek's plea for contextualization of research not only on career development.

Fred Vondracek was an inspiring source not so much because of his particular scientific interests, but because of his creative mindset and great support for research and application aimed at a better world for young people. He has been a translator and mediator between cultures and scientific communities because he knew from his own experience of countries where in the case of economic trouble, seniority counts in maintaining a job, such as in the USA, as well as countries that provide particular shields to (also) sponsor youth, like Germany.

In closing, we should hasten to add that we did not follow Fred's own thinking about the complexities of the motivational processes involved, although we also relied on goal-directed action as a major propellant of development in context, but we were more interested in the effects of contextual change than in the intricacies of the individuals' inner workings. The price is that with our approach we cannot offer finely tuned concepts of how to enable individuals to optimize their development in spite of threatening challenges of uncertainty about the future. But probably this is work still to come. At a minimum, we know that a crucial capability in dealing with social change is identifying opportunities and contexts and based on that, exercising full engagement to resolve challenges. 


\section{References}

Arts, W. \& Gelissen, J. (2002). Three worlds of welfare capitalism or more? A state-of-the-art report. Journal of European Social Policy, 12, 137-158. doi:10.1177/0952872002012002114

Baltes, P. B., Lindenberger, U., \& Staudinger, U. M. (2006). Life span theory in developmental psychology. In R. M. Lerner \& W. Damon (Eds.), Handbook of child psychology (6 ed., pp. 569-664). Hoboken, NJ: Wiley.

Bergman, L. R. \& Magnusson, D. (1997). A person-oriented approach in research on developmental psychopathology. Development and Psychopathology, 9, 291-319.

Berth, H., Förster, P., Brähler, E., \& Stöbel-Richter, Y. (2007). Einheitslust und Einheitsfrust. Junge Ostdeutsche auf dem Weg vom DDR-zum Bundesbürger. Eine sozialwissenschaftliche Längsschnittstudie von 1987-2006. Gießen: Psychosozial-Verlag.

Christmas-Best, V. E. \& Schmitt-Rodermund, E. (2001). Adolescents' career choices in East and West Germany after unification: Interregional and intraregional differences and the role of gender. American Behavioral Scientist, 44, 1879-1898.

Clark, A., Knabe, A., \& Rätsel, S. (2010). Boon or bane? Others' unemployment, well-being and job insecurity. Labour Economics, 17, 52-61.

Conger, R. D. \& Elder, G. H. Jr. (1994). Families in troubled times: Adapting to change in rural America. Hawthorne, NY: Aldine DeGruyter.

Elder, G. H., Jr. (1994). Time, human agency, and social change: Perspectives on the life course. Social Psychology Quarterly, 57(1), 4-15.

Euler, D. (2013). Germany's dual vocational training system: A model for other countries? A study commissioned by the Bertelsmann Stiftung. Retrieved from http://www.bertelsmann-stiftung.de/de/publikationen/publikation/ did/germanys-dual-vocational-training-system/.

Folkman, S. \& Moskowitz, J. T. (2004). Coping: Pitfalls and promise. Annual Review of Psychology, 55, 745-774.

Grümer, S., Silbereisen, R. K., \& Heckhausen, J. (2013). Subjective well-being in times of social change: Congruence of control strategies and perceived control. International Journal of Psychology, 48, 1246-1259.

Hartung, P. J., Porfeli, E. J., \& Vondracek, F. W. (2005). Child vocational development: A review and reconsideration. Journal of Vocational Behavior, 66(3), 385-419.

Heckhausen, J., Wrosch, C., \& Schulz, R. (2010). A motivational theory of lifespan development. Psychological Review, 117, 32-60.

Juang, L., Reitzle, M., \& Silbereisen, R. K. (2000). The adaptability of transitions to adulthood under social change: The case of German unification. European Review of Applied Psychology, 50, 275-282.

Kokko, K., Bergman, L. R., \& Pulkkinen, L. (2003). Child personality characteristics and selection into long-term unemployment in Finnish and Swedish longitudinal samples. International Journal of Behavioral Development, 27, 134-144. doi: 10.1080/01650250244000137 
Körner, A., Lechner, C. M., Pavlova, M. K., \& Silbereisen, R. K. (2015). Goal engagement in coping with occupational uncertainty predicts favorable career-related outcomes. Journal of Vocational Behavior, 88, 174-184.

Körner, A., Reitzle, M., \& Silbereisen, R. K. (2012). Work-related demands and life satisfaction: The effects of engagement and disengagement among employed and long-term unemployed people. Journal of Vocational Behavior, 80, 187-196.

Kracke, B. \& Schmitt-Rodermund, E. (2001). Adolescents' career exploration in the context of educational and occupational transitions. In J. E. Nurmi (Ed.), Navigating through adolescence: European perspectives (pp. 141-165). New York: Routledge.

McClelland, D. L. (1961). Entrepreneurial behavior. In D. L. McClelland, The achieving society (pp. 205-258). New York: Van Nostrand Company.

Obschonka, M. (2013). Entrepreneurship as 21st century skill: Taking a developmental perspective. In Coetzee, M. (Ed.). Psycho-social career metacapacities: Dynamics of contemporary career development (pp. 293306). Amsterdam: Springer.

Obschonka, M., Andersson; H., Silbereisen, R. K., \& Sverke, M. (2013). Rulebreaking, crime, and entrepreneurship: A replication and extension study with 37-year longitudinal data. Journal of Vocational Behavior, 83, 386-396. doi:10.1016/j.jvb.2013.06.007

Obschonka, M., Duckworth, K., Silbereisen, R. K., \& Schoon, I. (2012). Social competencies in childhood and adolescence and entrepreneurship in young adulthood: A two-study analysis. International Journal of Developmental Science. 6, 137-150. doi:10.3233/DEV-2012-12108

Obschonka, M., Schmitt-Rodermund, E., Silbereisen, R. K., Gosling, S. D., \& Potter, J. (2013). The regional distribution and correlates of an entrepreneurshipprone personality profile in the United States, Germany, and the United Kingdom: A socioecological perspective. Journal of Personality and Social Psychology, 105(1), 104-122.

Obschonka, M., Silbereisen, R. K., Goethner, M., \& Cantner, U. (2015). Entrepreneurial self-identity: Predictors and effects within the theory of planned behavior framework. Journal of Business and Psychology, 30(4), 773-794.

Obschonka, M., Silbereisen, R. K., \& Schmitt-Rodermund, E. (2010). Entrepreneurial intentions as developmental outcome. Journal of Vocational Behavior, 77, 63-72. doi:10.1016/j.jvb.2010.02.008

Obschonka, M., Silbereisen, R. K., \& Schmitt-Rodermund, E. (2011). Successful entrepreneurship as developmental outcome: A path model from a life span perspective of human development. European Psychologist. 16, 174186. doi: $10.1027 / 1016-9040 / \mathrm{a} 000075$

Obschonka, M., Silbereisen, R. K., \& Schmitt-Rodermund, E. (2012). Explaining entrepreneurial behavior: Dispositional personality traits, growth of personal entrepreneurial resources, and business idea generation. The Career Development Quarterly, 60(2), 178-190.

Obschonka, M., Silbereisen, R. K., Schmitt-Rodermund, E., \& Stuetzer, M. (2011). Nascent entrepreneurship and the developing individual: Early entrepreneurial 
competence in adolescence and venture creation success during the career. Journal of Vocational Behavior, 79, 121-133. doi:10.1016/j.jvb.2010.12.005

Obschonka, M., Silbereisen, R. K., \& Wasilewski, J. (2012). Constellations of new demands concerning careers and jobs: Results from a two-country study on social and economic change. Journal of Vocational Behavior, 80, 211-223. doi:10.1016/j.jvb.2011.08.002

Pavlova, M. K., Körner, A., \& Silbereisen, R. K. (2015). Perceived social support, perceived community functioning, and civic participation across the life span: Evidence from the former East Germany. Research in Human Development, 12 (1-2), 100-117. doi: 10.1080/15427609.2015.1010351

Pavlova, M. K. \& Silbereisen, R. K. (2012). Participation in voluntary organizations and volunteer work as a compensation for the absence of work or partnership? Evidence from two German samples of younger and older adults. The Journals of Gerontology, Series B: Psychological Sciences and Social Sciences, 67, 514-524.

Pavlova, M. K. \& Silbereisen, R. K. (2014). Coping with occupational uncertainty and formal volunteering across the life span. Journal of Vocational Behavior, 85, 93-105.

Pinquart, M., Silbereisen, R. K., \& Körner, A. (2009). Perceived work-related demands associated with social change, control strategies, and psychological well-being: Do associations vary by regional economic conditions? Evidence from Germany. European Psychologist, 14, 207-219.

Reitzle, M. \& Silbereisen, R. K. (2000).The timing of adolescents' school-towork transition in the course of social change: The example of German unification. Swiss Journal of Psychology, 59, 240-255. doi: 10.1024//14210185.59 .4 .240

Reitzle, M., Vondracek, F. W., \& Silbereisen, R. K. (1998). Timing of school-towork transitions: A developmental-contextual perspective. International Journal of Behavioral Development, 22, 7-28. doi:10.1080/016502598384496

Reinhart, C. M. \& Rogoff, K. S. (2013). Financial and Sovereign Debt Crises: Some lessons learned and those forgotten. International Monetary Fund Working Paper, 13, 266.

Rotolo, T. \& Wilson, J. (2003). Work histories and voluntary association memberships. Sociological Forum, 18, 603-619.

Ruiter, S. \& De Graaf, N. D. (2009). Socio-economic payoffs of voluntary association involvement: A Dutch life course study. European Sociological Review, 25, 425-442.

Savickas, M. L. (1997). Career adaptability: An integrative construct for lifespan, life-space theory. Career Development Quarterly, 45, 247-259.

Schmitt-Rodermund, E. (2004). Pathways to successful entrepreneurship: Parenting, personality, competence, and interests. Journal of Vocational Behavior, 65, 498-518.

Schmitt-Rodermund, E. (2007). The long way to entrepreneurship. Personality, parenting, early interests and competencies for entrepreneurial activity among the "Termites". R. K. Silbereisen \& R. M. Lerner (Eds.), Approaches to positive youth development, 205-224. Thousand Oaks: Sage. 
Schmitt-Rodermund, E. \& Schröder, E. (2004). Wer hat das Zeug zum Unternebmer? Ein Training zur Förderung unternebmerischer Potenziale. [Who can be an entrepreneur? A training program to foster entrepreneurial potentials]. Göttingen: Hogrefe.

Schmitt-Rodermund, E. \& Silbereisen, R. K. (1998). Career maturity determinants: Individual development, historical time, and situational context. The Career Development Quarterly, 47, 16-31.

Schmitt-Rodermund, E., \& Silbereisen, R. K. (1999). Determinants of differential acculturation of developmental timetables among adolescent immigrants to Germany. International Journal of Psychology, 34, 219233. doi:10.1080/002075999399864

Schmitt-Rodermund, E., \& Silbereisen, R. K. (2009). Immigrant parents' age expectations for the development of their adolescent offspring: Transmission effects and changes after immigration. In U. Schoenpflug (ed.), Cultural transmission: Psychological, developmental, social, and methodological aspects. Cambridge: Cambridge University Press.

Schmitt-Rodermund, E. \& Vondracek, F. W. (1999). Breadth of interests, exploration, and identity development in adolescence. Journal of Vocational Behavior, 55, 298-317.

Schröder, E. \& Schmitt-Rodermund, E. (2006). Crystallizing enterprising interests among adolescents through a career development program: The role of personality and family background. Journal of Vocational Behavior, 69, 494-509.

Schröder, E. \& Schmitt-Rodermund, E. (2007). Development of entrepreneurial interests, attitudes, and behaviors. In V. Skorikov \& W. Patton (Eds.), Career Development in Childhood and Adolescence (pp. 127-142). Rotterdam: Sense Publishers.

Schröder, E. \& Schmitt-Rodermund, E. (2013). Antecedents and consequences of adolescents' motivations to join the family business. Journal of Vocational Behavior, 83, 476-485.

Schröder, E., Schmitt-Rodermund, E., \& Arnaud, N. (2011). Career choice intentions of adolescents with a family business background. Family Business Review, 24, 305-321.

Silbereisen, R. K. (2000). German unification and adolescents' developmental timetables: Continuities and discontinuities. In: L. Crockett \& R. K. Silbereisen (eds.), Negotiating adolescence in times of social change (pp. 104-122). Cambridge, MA: Cambridge University Press.

Silbereisen, R. K., Eyferth, K., \& Rudinger, G. (Eds.) (1986). Development as action in context: Problem behavior and normal youth development. Heidelberg, New York: Springer.

Silbereisen, R. K., Titzmann, P. F., \& Shavit, Y.(2014) (eds.). The challenges of Diaspora migration: Interdisciplinary perspectives on Israel and Germany. Farnham: Ashgate.

Silbereisen, R. K. \& Todt, E. (eds.) (1994). Adolescence in context: The interplay of family, school, peers, and work in adjustment. New York: Springer.

Silbereisen, R. K., Vaskovics, L. A., \& Zinnecker, J. (eds.) (1996). Jungsein in Deutschland. Opladen: Leske \& Budrich. 
Silbereisen, R. K. \& Zinnecker, J. (1999). Entwicklung im sozialen Wandel. Weinheim: Psychologie Verlags Union.

Statista (2015). Youth unemployment rate in the European Union and the euro area from 2004 to 2013. Retrieved from http://www.statista.com/ statistics/253519/youth-unemployment-rate-in-the-european-union-andthe-euro-area/.

Super, D. E., Savickas, M. L., \& Super, C. M. (1996). The life-span, life-space approach to careers. In D. Brown \& L. Brooks (Eds.), Career choice and development (3 ed., pp. 121-178). San Francisco, CA: Jossey-Bass.

Tomasik, M. J. \& Silbereisen, R. K. (2009). Demands of social change as a function of the political context, institutional filters, and psychosocial resources. Social Indicators Research, 94, 13-28.

Tomasik, M. J. \& Silbereisen, R. K. (2012). Beneficial effects of disengagement from futile struggles with occupational planning: A contextualist-motivational approach. Developmental Psychology, 48, 1785-1796.

Tomasik, M. J., Silbereisen, R. K., \& Heckhausen, J. (2010). Is it adaptive to disengage from demands of social change? Adjustment to developmental barriers in opportunity-deprived regions. Motivation and Emotion, 34 , 384-398.

Vondracek, F. W. \& Porfeli, E. (2002). Integrating person- and function-centered approaches in career development theory and research. Journal of Vocational Behavior, 61, 386-397.

Vondracek, F. W. (2001). The developmental perspective in vocational psychology. Journal of Vocational Behavior, 59, 252-261.

Vondracek, F. W., Ferreira, J. A. G., \& dos Santos, E. J. R. (2010). Vocational behavior and development in times of social change: New perspectives for theory and practice. International Journal for Educational and Vocational Guidance, 10, 125-138.

Vondracek, F. W., Lerner, R. M., \& Schulenberg, J. E. (1986). Career development: A life-span developmental approach. Hillsdale, NJ: Erlbaum Associates.

Wiesner, M., Weichold, K., \& Silbereisen, R. K. (2007). Trajectories of alcohol use among adolescent boys and girls: Identification, validation, and sociodemographic characteristics. Psychology of Addictive Behaviors, 21, 62-75. doi:10.1037/0893-164X.21.1.62

Wiesner, M., Weichold, K., \& Silbereisen, R. K. (2008). Effects of deviant peer association on adolescent alcohol consumption: A growth mixture modelling analysis. Journal of Youth and Adolescence, 37, 537-551. doi:10.1007/ s10964-007-9263-6

Wilson, J. \& Musick, M. A. (2003). Doing well by doing good: Volunteering and occupational achievement among American women. The Sociological Quarterly, 44, 433-450. 


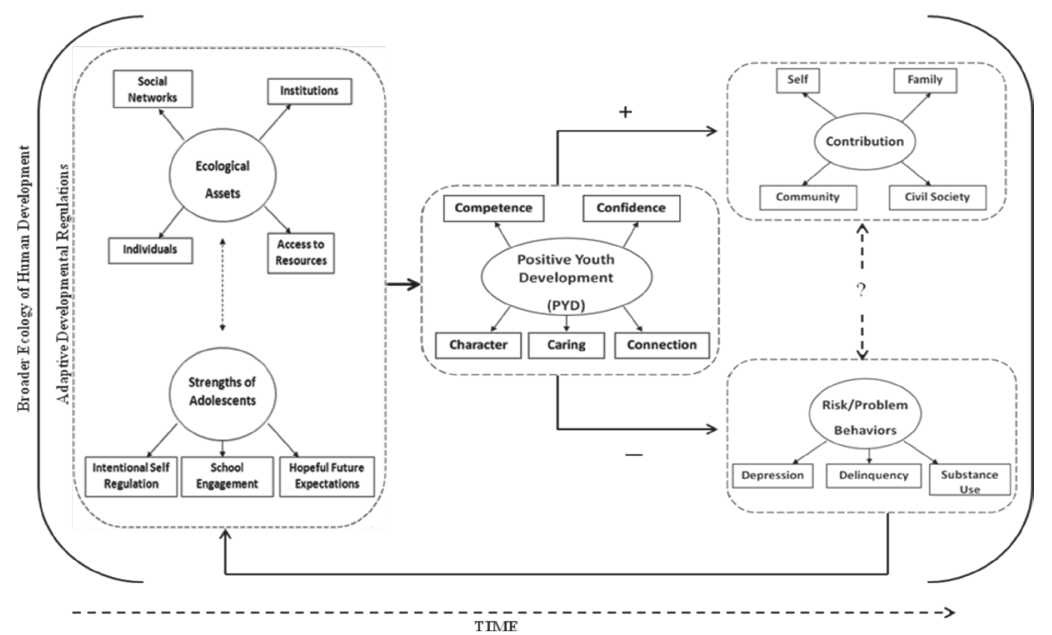

Figure 1. A relational, developmental systems model of the individual $\leftarrow \rightarrow$ context relations involved in the Lerner and Lerner conception of the PYD developmental process. 